\title{
Next Generation Light Robotics
}

\section{Glückstad, Jesper}

Publication date:

2017

\section{Document Version}

Publisher's PDF, also known as Version of record

Link back to DTU Orbit

\section{Citation (APA):}

Glückstad, J. (2017). Next Generation Light Robotics. Paper presented at 13th Mediterranean Workshop and Topical Meeting, Cetraro, Italy.

\section{General rights}

Copyright and moral rights for the publications made accessible in the public portal are retained by the authors and/or other copyright owners and it is a condition of accessing publications that users recognise and abide by the legal requirements associated with these rights.

- Users may download and print one copy of any publication from the public portal for the purpose of private study or research.

- You may not further distribute the material or use it for any profit-making activity or commercial gain

- You may freely distribute the URL identifying the publication in the public portal

If you believe that this document breaches copyright please contact us providing details, and we will remove access to the work immediately and investigate your claim 


\title{
Next Generation Light Robotics
}

\author{
Jesper Glückstad \\ DTU Fotonik, Dept. of Photonics Engineering \\ Techn. University of Denmark, Ørsted Plads 343 \\ DK-2800 Kgs. Lyngby, Denmark \\ Email: jesper.gluckstad@fotonik.dtu.dk \\ www.ppo.dk www.GPCphotonics.com www.OptoRobotix.com
}

Light Robotics is a new field of research where ingredients from photonics, nanotechnology and biotechnology are put together in new ways to realize light-driven robotics at the smallest scales to solve major challenges primarily within the nanobio-domain but not limited hereto. Exploring the full potential of this new 'drone-like' light-printed, light-driven, light-actuated micro- and nano-robotics in challenging geometries requires a versatile and real-time reconfigurable light addressing that can dynamically track a plurality of tiny tools in 3D to ensure real-time continuous light-delivery on the fly. Our latest developments in this new and exciting research area will be reviewed at NOMA 2017.

Step by step we are beginning to see the many intriguing possibilities of directly equipping 3Dprinted Light Robotics equipped with multi-functional nanoprobes, nanotips or nanotapers fabricated with true nanoscopic resolution. The uniqueness of this approach is that even if a user aims at exploring e.g. micro-biology at subcellular scales, the main support of each Light Robotic structure can be designed with size and shape that allows convenient manipulation with even moderate NA objective lenses. Each Light Robotic structure is printed with convenient micron-sized spherical "handles" that allow for volumetric laser-manipulation with six-degrees-of-freedom (6-DOF) and in full real-time. Thereby, a drone-like functionality can be obtained which can almost provide the user with the sensation of stretching one's hands directly into the cellular micro-environment with the ability to interact with the live specimen directly while observing in full 3D.
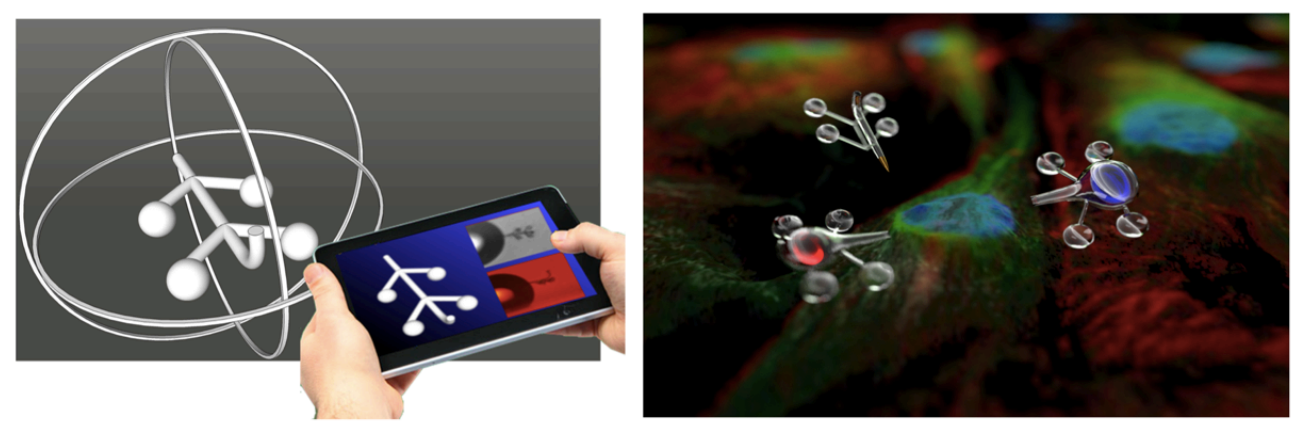

Figure 1: Light Robotics with 3D real-time microscopic drone-like functionality

Using contemporary two-photon polymerization we can directly 3D-print a plurality of Light Robotic structures equipped with nanoprobes, nanotips and nano-tapers with high resolution and fidelity. This is unique since a user can perform active cell biology interactions at tiny scales even though the main structure has a size and shape that allows convenient microscopic observation and laser manipulation with moderate numerical aperture optics. Some of our earlier experimental demonstrations are illustrated below. We have demonstrated simultaneous top and side-view imaging giving the required 3D sensation when navigating the microscopic tools in a volume in real-time and with 6-DOF. The latest generation of our Light Robotic tools 
are capable of material transport and incorporates a syringe action for loading and unloading a tiny cargo. The field of Light Robotics is still so new and promising that we have only just started to "scratch the surface" both scientifically and R\&D-wise. With the fast-paced development of new Augmented Reality tools such as e.g. Microsoft's Hololens, Artificial Intelligence and Machine Learning, advanced Swarm Robotics techniques and new 3D visualisation and manipulation modalities combined with state-of the-art Nano-biophotonics, the full scope of Light Robotics is obviously only in its infancy. Hence, we decided to edit a book volume including a variety of the ingredients needed to explore the full potential of Light Robotics and to trigger further rapid advancement of this exciting new research discipline.

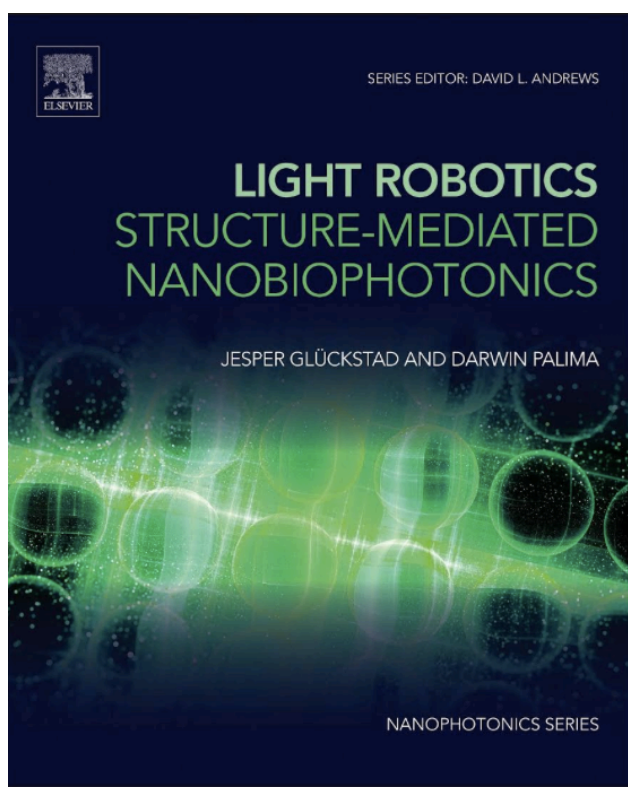

Figure 2: Upcoming book on Light Robotics- the first on the topic.

[1] Glückstad, J., Nature Photonics 5, 7-8 (2011).

[2] Palima, D ., Glückstad, J., Laser and Photon. Rev. 7, 478-494 (2013).

[3] Rodrigo, P. J., Gammelgaard, L., Bøggild, P., Perch-Nielsen, I., Glückstad, J., Opt. Express 13, 6899-6904 (2005).

[4] Rodrigo, P. J., Kelemen, L., Palima, D., Alonzo, C., Ormos, P., Glückstad, J., Opt. Express 17, 6578-6583 (2009).

[5] Wu, C.W., Palima, D., Novitsky, A; Ding, W., Gao, D., Shukovsky, S., and Glückstad, J., Nanophotonics 3, 181-201 (2014).

[6] Villangca, M., Casey, D., Glückstad, J., Biophysical Reviews 7, 379-390 (2015).

[7] Palima, D., Bañas, A., Vizsnyiczai, G., Kelemen, L., Ormos, P., Glückstad, J., Opt. Express 20, 2004-2014 (2012).

[8] Villangca, M., Bañas, A., Palima, D., Glückstad, J., Opt. Express 22, 17880-17889 (2014).

[9] Villangca, M., Bañas, A., Palima, D., Glückstad, J. Opt. Eng. 54, 111308 (2015).

[10] Palima, D., Bañas, A., Vizsnyiczai, G., Kelemen, L., Aabo, T., Ormos, P., and Glückstad, J., "Optical forces through guided light deflections," Opt. Express 21, 581-593 (2013).

[11] Villangca, M., Palima, D., Bañas, A., Glückstad, J., "Light-driven micro-tool equipped with a syringe function," Light: Science \& Applications 5, e16148 (2016).

[12] Bañas, A., Glückstad, J., "Holo-GPC: Holographic Generalized Phase Contrast," Optics Communications 392, 190-195 (2017).

[13] Glückstad, J., Palima, D., "Light Robotics - Structure-mediated Nanobiophotonics," Elsevier Science, 486 pages (2017). 